\title{
Economical aspects of the CCS technology integration in the conventional power plant
}

\author{
Nela SLAVU \\ University Politehnica of Bucharest, Bucharest, Romania \\ Cristian DINCA \\ University Politehnica of Bucharest, Bucharest, Romania \\ crisflor75@yahoo.com
}

\begin{abstract}
One of the way to reduce the greenhouses gases emissions generated by the fossil fuels combustion consists in the Carbon Capture, Transport and Storage (CCS) technologies utilization. The integration of CCS technologies in the coal fired power plants increases the cost of the energy generation. The CCS technology could be a feasible solution in the case of a high value of a $\mathrm{CO}_{2}$ certificate but for the present value an optimization of the CCS technology integration in the power plants is expected. However, for reducing the cost of the energy generated in the case of CCS integration in the power plants, a parametrical study optimization of the $\mathrm{CO}_{2}$ capture process is required. In this study, the chemical absorption process was used and the monoethanolamine with $30 w t . \%$. The objective of this paper is to analyze the effects of the package type used in the absorption column on the size of the equipment used and, on the energy cost of the power plant with $\mathrm{CO}_{2}$ capture process consequently. The packages types analyzed in this paper are metal Pall rings with different sizes and the rings are made of different metals: aluminum, nickel, cooper, and brass. In the case of metal Pall rings, the utilization of different material has an impact on the absorption column weight. Also, Pall rings made of plastics (polypropylene and polyethylene) were analyzed. The comparative assessment was achieved for a coal fired power plant with an installed power of $100 \mathrm{MW}$ and considering the $\mathrm{CO}_{2}$ capture process efficiency of $90 \%$.
\end{abstract}

Keywords: coal, power plant, CCS, chemical absorption, monoethanolamine.

\section{Introduction}

In the last years, an important growing of carbon dioxide concentration in the atmosphere was observed. This tendency is caused by the industry development and the raising of global living standards. The International Energy Agency (IEA) recommends the diminishing at least $80 \%$ of carbon dioxide emissions from the energy sector until 2050 , for reducing the climate change effect. Nowadays, only the fossil fuels and nuclear energy primary resources are not enough to respond of the global energy requirements (Rahman et al., 2017, Badea et al., 2010).

Nowadays, the development of the energy sector only by using both the renewable energy and nuclear power plants is not sufficient to assure the electricity requirements at the global scale. On the other hand, the utilization of the fossil fuels for electricity production generate in the environment a large amount of emissions (Dinca, 2013). For example, the amount of the $\mathrm{CO}_{2}$ emissions generated in the environment depends on the combustion technology type (e.g. Circulated Fluidized Bed Combustion technology, Pulverized technology, etc.), on the fuel type (e.g. in the case of lignite combustion, $850 \mathrm{~kg}_{-} \mathrm{CO}_{2} / \mathrm{MWh}$ is generated, but for natural gas utilization, $450 \mathrm{~kg} \mathrm{CO}_{2}$ are emitted for each MWh) (Dinca, 2016). In order to avoid the increasement of the power plant environmental impact, the CCS (Carbon Capture, Transport and Storage) technologies are required to be integrated in the fossil fuels power plants (Norisor et al., 
2012). In the last decades, a lot of CCS technologies was developed but not all are mature to be applied both in the energy or industrial sector. However, the post-combustion technologies are the most developed today comparing to the others (Porter et al., 2016). In this context, one technology, the chemical absorption process, could be applied both for new or existing power plants. Despite of its flexibility, the chemical absorption process integration in a power plant has a negative impact on the power plant global efficiency due to the amount of steam required for chemical solvents regeneration (Dinca and Badea, 2013). Additionally, the integration of the chemical absorption process leads to the electricity cost increase with 30-70\% (according to the power plant used) (Liang et al., 2016).

In this way, in the present study the authors studied the equipment of the chemical absorption process in order to optimize them and to reduce the electricity cost. Consequently, the power installed in the coal fired power plant analyzed in the paper is $100 \mathrm{MW}$, and in the chemical absorption process used for $\mathrm{CO}_{2}$ separation the monoethanolamine $30 \mathrm{wt}$ \% is assumed to be used.

\section{Coal fired power plant}

The chemical absorption technology is integrated into a power plant with a power installed of $100 \mathrm{MW}$. In Table 1 is presented the lignite and flue gases composition, the flue gases composition is for dry and wet gases.

Table 1. Lignite and flue gases composition

\begin{tabular}{|l|l|l|l|l|l|l|l|}
\hline \multicolumn{6}{|l|}{ Elementary lignite composition } \\
\hline $\begin{array}{l}\mathrm{C}^{\mathrm{i}} \\
{[\%]}\end{array}$ & $\begin{array}{l}\mathrm{H}^{\mathrm{i}} \\
{[\%]}\end{array}$ & $\begin{array}{l}\mathrm{S}^{\mathrm{i}} \\
{[\%]}\end{array}$ & $\begin{array}{l}\mathrm{O}^{\mathrm{i}} \\
{[\%]}\end{array}$ & $\begin{array}{l}\mathrm{N}^{\mathrm{i}} \\
{[\%]}\end{array}$ & $\begin{array}{l}\mathrm{W}^{\mathrm{i}} \\
{[\%]}\end{array}$ & $\begin{array}{l}\mathrm{A}^{\mathrm{i}} \\
{[\%]}\end{array}$ & $\begin{array}{l}\mathrm{LHV} \\
{[\mathrm{kJ} / \mathrm{kg}]}\end{array}$ \\
\hline 35 & 1 & 1 & 2 & 2 & 27 & 32 & 12110 \\
\hline Flue gases composition & 1 & & Wet gases \\
\hline \multicolumn{7}{|c|}{ Dry gases } & 11.6255 \\
\hline $\mathrm{CO}_{2},[\%]$ & 12.6306 & 0.1244 & \\
\hline $\mathrm{SO}_{2},[\%]$ & 0.1352 & 73.2984 \\
\hline $\mathrm{N}_{2},[\%]$ & 79.6352 & 6.9944 & \\
\hline $\mathrm{O}_{2},[\%]$ & 7.5991 & 7.9573 & \\
\hline $\mathrm{H}_{2} \mathrm{O},[\%]$ & - & & \\
\hline
\end{tabular}

Table 2. Main data of the power plant

\begin{tabular}{|l|l|l|}
\hline Parameter & Values & U.M. \\
\hline Power installed & 100 & {$[\mathrm{MW}]$} \\
\hline Pressure steam & 190 & {$[\mathrm{bar}]$} \\
\hline HP steam & 550 & {$\left[{ }^{\circ} \mathrm{C}\right]$} \\
\hline MP steam & 550 & {$\left[{ }^{\circ} \mathrm{C}\right]$} \\
\hline Average annual temperature river water & 15 & {$\left[{ }^{\circ} \mathrm{C}\right]$} \\
\hline Average annual temperature water from cooling tower & 22 & {$\left[{ }^{\circ} \mathrm{C}\right]$} \\
\hline River water share in total flow cooling water & 25 & {$[\%]$} \\
\hline Net power plant efficiency & 39.23 & {$[\%]$} \\
\hline Flow rate fuel & 66.45 & {$[\mathrm{t} / \mathrm{h}]$} \\
\hline Mass flow rate flue gases & 372968 & {$[\mathrm{~kg} / \mathrm{h}]$} \\
\hline Volumetric flow rate flue gases & 381159 & {$[\mathrm{Nm} / \mathrm{h}]$} \\
\hline Electricity generated & 485649 & {$[\mathrm{TWh} / \mathrm{an}]$} \\
\hline
\end{tabular}

Source: Authors' own research.

The main data of the lignite power plant are shown in Table 2. It was calculated the flow rate fuel, the flow rate flue gases for an excess air of 1.56 and the amount of electricity produced for an annual power plant operation of $6000 \mathrm{~h} /$ year. In the case of determining the net power plant efficiency was used thermodynamic cycle diagram 
shown in Figure 1. In this case, the thermodynamic cycle is composed of 3 preheaters for low/high pressure and a degasser. The fuel combustion efficiency is of $85.87 \%$.

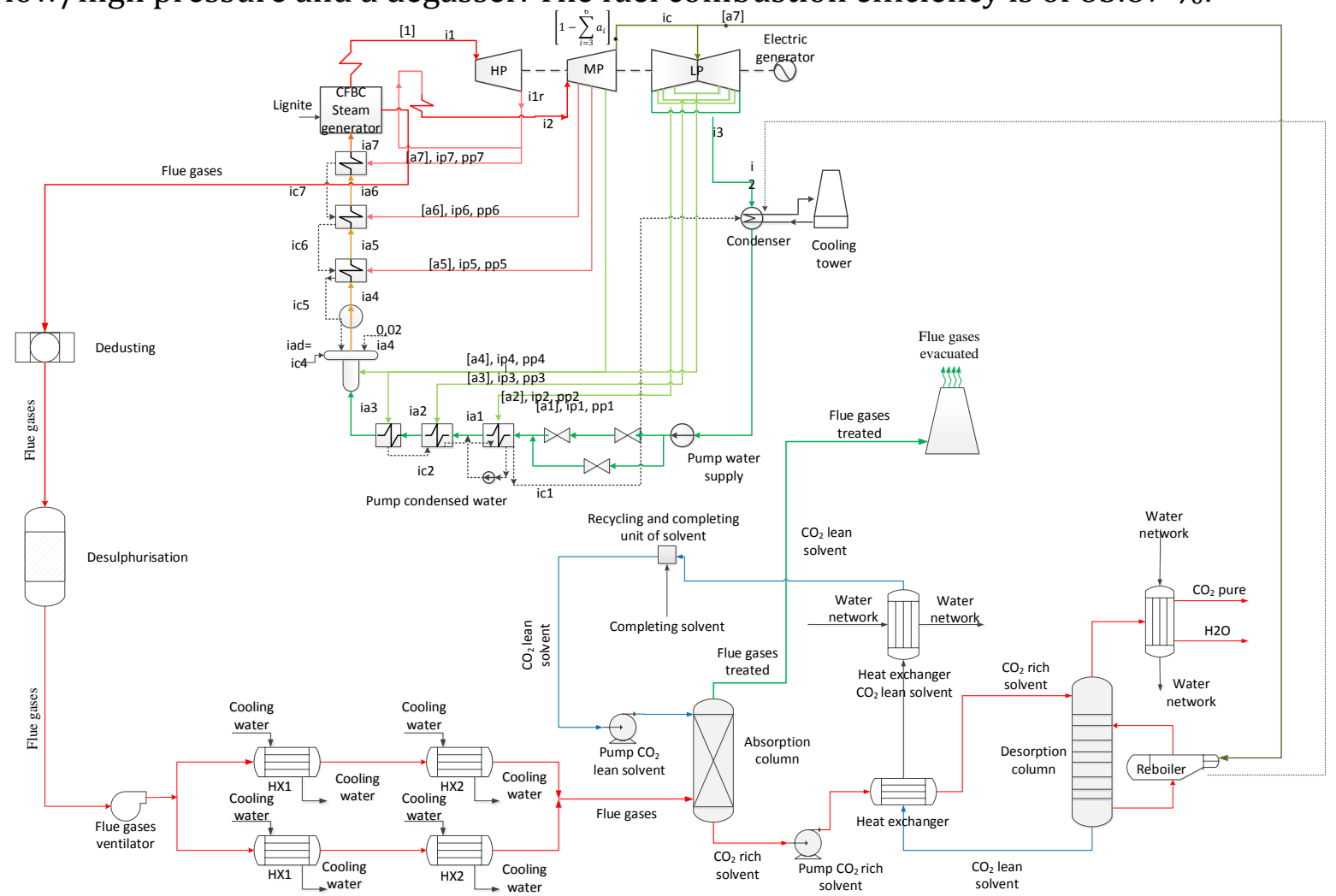

PICBE $\mid 170$

Figure 1. Power plant with $\mathrm{CO}_{2}$ capture

Source: Dinca and Badea, 2013.

The technology for $\mathrm{CO}_{2}$ capture by chemical absorption consists of passing the flue gases in countercurrent through an absorption column (Figure 2) where the flue gases are mixed with the amines solution. The flue gases treated leaving the absorption column at the top, while the $\mathrm{CO}_{2}$ rich solvent exits at the bottom. The $\mathrm{CO}_{2}$ rich solvent enters a heat exchanger which recovers a part of the heat transferred by the $\mathrm{CO}_{2}$ lean solvent. The regeneration of the $\mathrm{CO}_{2}$ rich solvent is performed in the desorption column. The amount of thermal energy required for the rich solvent regeneration is obtained by using a steam ratio from the low pressure steam turbine. The $\mathrm{CO}_{2}$ lean solvent enters in the absorption column at the top, not before to transfer a part of heat the $\mathrm{CO}_{2}$ rich solvent. In order to meet the requirements of the mass concentrations of solvent in the amine solution is added a new amount of amine. The process pressure is obtained by using pumps (Dinca and Badea, 2013).

In the process of $\mathrm{CO}_{2}$ capture by chemical absorption are encountered the following equipment: flue gases ventilator, system of cooling flue gases, two heat exchangers (liquid/liquid), absorption column, desorption column, pumps used to transport the solvent or the water cooling, monitoring equipment of the different parameters of the process, chemical solvent recycling system, recipient with new chemical solvent in order to maintain the same mass concentrations of the solvent. 


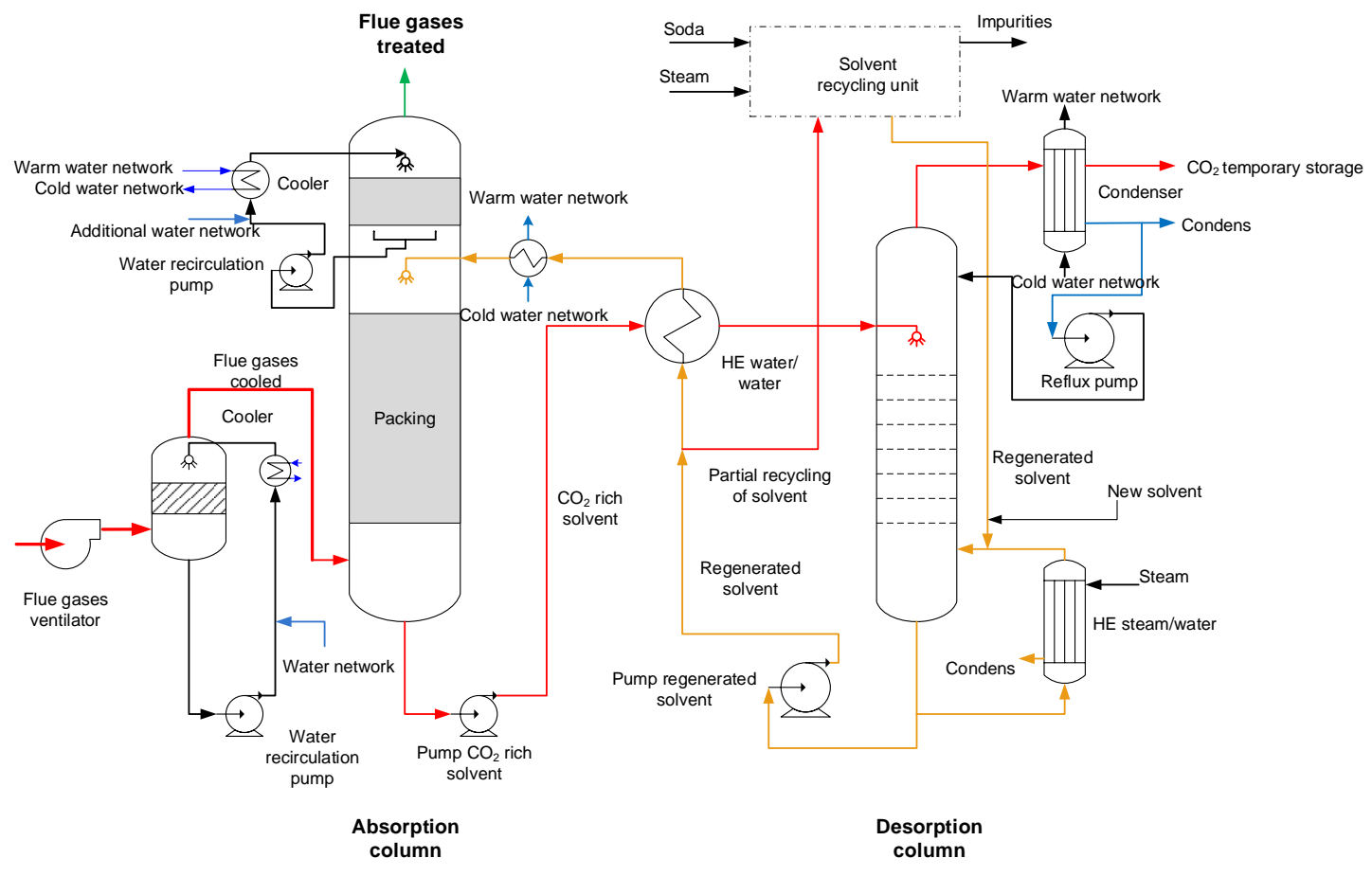

PICBE| 171

Figure 2. Chemical absorption process

Source: Dinca et al., 2015.

\section{Modeling equipments chemical absorption process}

The flue gases are evacuated at atmospheric pressure and at a temperature higher than the ambient temperature, in the range $70-90{ }^{\circ} \mathrm{C}$ (Dinca et al., 2015). In this case, it is used a flue gases ventilator to increase the pressure required the process, in order to cover the pressure drop in the absorption - desorption columns. The power required of the flue gases ventilator in the case studied was calculated, it is of 2.921 [MW].

The flue gases temperature the entry into the cooling system is higher than the flue gases temperature upstream of the flue gas ventilator, as a result of the increase enthalpy, due the increase the pressure (Rahman et al., 2017). The cooling is performed in "2 steps" due the high temperature of the flue gases $\left(150-155^{\circ} \mathrm{C}\right)$ and the high flow of the combustion gases (Figure 3). Thus it is reduced the size of the equipments used and is obtained a higher efficiency of the cooling process flue gases. The cooling system is composed of 4 fin-and-tube heat exchangers (HX). In the "first step" the combustion gases are cooled from the $155{ }^{\circ} \mathrm{C}$ to about $120{ }^{\circ} \mathrm{C}$, and in the "second step" from the 120 ${ }^{0} \mathrm{C}$ to about $50{ }^{\circ} \mathrm{C}$. The heat exchangers are considered identical, further is presented the calculation for the single-line cooling (Singh et al., 2017).

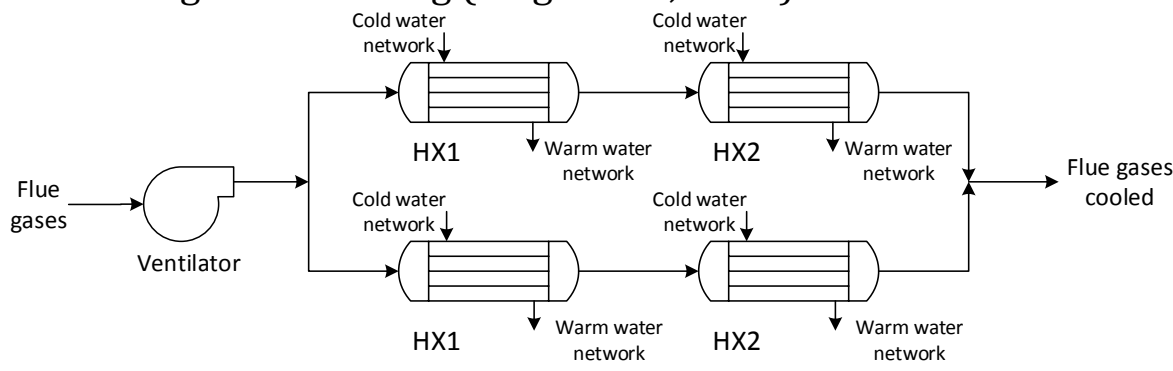

Figure 3. System of cooling flue gases

Source: Authors' own research. 
In the Table 3 are shown the entry data for the fin-and-tube heat exchanger. The primary agent is represented of the flue gases and the secondary agent of water. The obtained results are presented in the Table 4.

Table 3. Entry data fin-and-tube heat exchanger

\begin{tabular}{|l|l|l|l|l|}
\hline Parameter & Notation & Value & U.M \\
\cline { 3 - 4 } & & HX1 & HX2 & \\
\hline Mass flow rate primary agent & $\dot{m}_{1}$ & 51.8 & 51.8 & {$[\mathrm{~kg} / \mathrm{s}]$} \\
\hline Inlet temperature primary agent & $T_{1}^{\prime}$ & 155 & 120 & {$\left[{ }^{0} \mathrm{C}\right]$} \\
\hline Outlet temperature primary agent & $T_{1}^{\prime \prime}$ & 120 & 50 & {$\left[{ }^{0} \mathrm{C}\right]$} \\
\hline Inlet temperature secondary agent & $T_{2}^{\prime}$ & 10 & 10 & {$\left[{ }^{0} \mathrm{C}\right]$} \\
\hline Outlet temperature secondary agent & $T_{2}^{\prime \prime}$ & 43 & 43 & {$\left[{ }^{0} \mathrm{C}\right]$} \\
\hline Pressure primary agent & $p_{1}$ & 2.25 & 1.75 & {$[\mathrm{bar}]$} \\
\hline Pressure secondary agent & $p_{2}$ & 1.4 & 1.4 & {$[\mathrm{bar}]$} \\
\hline Outer diameter tube & $d_{e}$ & 0.04 & 0.04 & {$[\mathrm{~m}]$} \\
\hline Inner diameter tube & $d_{i}$ & 0.035 & 0.035 & {$[\mathrm{~m}]$} \\
\hline Diameter fin & $d_{a}$ & 0.06 & 0.06 & {$[\mathrm{~m}]$} \\
\hline Pitch fin & $b$ & 0.005 & 0.005 & {$[\mathrm{~m}]$} \\
\hline Thickness fin & $\delta_{a}$ & 0.0005 & 0.0005 & {$[\mathrm{~m}]$} \\
\hline Pinch transversal bundle tubes & $x_{t}$ & 0.065 & 0.065 & {$[\mathrm{~m}]$} \\
\hline Pinch in depth bundle tubes & $x_{a}$ & 0.075 & 0.075 & {$[\mathrm{~m}]$} \\
\hline Velocity primary agent in free section & $w_{1}$ & 7 & 7 & {$[\mathrm{~m} / \mathrm{s}]$} \\
\hline Velocity secondary agent in free section & $w_{2}$ & 0.5 & 0.5 & {$[\mathrm{~m} / \mathrm{s}]$} \\
\hline Efficiency heat exchanger & $\eta_{s c h}$ & 97 & 97 & {$[\%]$} \\
\hline
\end{tabular}

PICBE 172

Table 4. Fin-and-tube heat exchanger

\begin{tabular}{|c|c|c|c|c|}
\hline \multirow[t]{2}{*}{ Parameter } & \multirow[t]{2}{*}{ Equation } & \multicolumn{2}{|l|}{ Value } & \multirow[t]{2}{*}{ U.M } \\
\hline & & HX1 & HX2 & \\
\hline Thermal load & $\dot{Q}_{1}=\dot{m}_{1} \cdot c_{p 1} \cdot\left(T_{1}^{\prime}-T_{1}^{\prime \prime}\right)$ & 2.148 & 4.312 & {$[\mathrm{~W}]$} \\
\hline $\begin{array}{l}\text { Amount heat } \\
\text { transferred secondary } \\
\text { agent }\end{array}$ & $\begin{array}{l}\dot{Q}_{2}=\dot{m}_{2} \cdot c_{p 2} \cdot\left(T_{2}^{\prime \prime}-T_{2}^{\prime}\right) \\
\dot{Q}_{2}=\eta_{s c h} \cdot \dot{Q}_{1}=\dot{Q}\end{array}$ & 2.084 & 4.183 & [W] \\
\hline $\begin{array}{l}\text { Logarithmic mean } \\
\text { temperature } \\
\text { difference ( } \varepsilon \text {-factor } \\
\text { correction, according } \\
\text { to } \mathrm{P} \text { and } \mathrm{R} \text { ) }\end{array}$ & $\begin{aligned} \Delta T_{m} & =\varepsilon \cdot \Delta T_{m c} \\
\Delta T_{m c} & =\frac{\left(T_{1}^{\prime \prime}-T_{2}^{\prime}\right)-\left(T_{1}^{\prime}-T_{2}^{\prime \prime}\right)}{\ln \frac{\left(T_{1}^{\prime \prime}-T_{2}^{\prime}\right)}{\left(T_{1}^{\prime}-T_{2}^{\prime \prime}\right)}}\end{aligned}$ & 105 & 46.6 & {$[\mathrm{~K}]$} \\
\hline Length fin & $h_{a}=\frac{d_{a}-d_{e}}{2}$ & 0.01 & 0.01 & {$[\mathrm{~m}]$} \\
\hline Degree of filling & $\gamma=1-\frac{d_{e}}{x_{t}} \cdot\left(1+2 \cdot \frac{h_{a}}{b} \cdot \frac{\delta_{a}}{d_{e}}\right)$ & 0.354 & 0.354 & - \\
\hline $\begin{array}{l}\text { Volumetric flow rate } \\
\text { primary agent }\end{array}$ & $\dot{V}_{1}=\frac{\dot{m}_{1}}{\rho_{1}}$ & 26.313 & 22.367 & {$\left[\mathrm{~m}^{3} / \mathrm{s}\right]$} \\
\hline Free section & $S_{1}=\frac{\dot{V}_{1}}{w_{1}}$ & 3.759 & 3.338 & {$\left[\mathrm{~m}^{2}\right]$} \\
\hline
\end{tabular}




\begin{tabular}{|c|c|c|c|c|}
\hline \multirow[t]{2}{*}{ Parameter } & \multirow[t]{2}{*}{ Equation } & \multicolumn{2}{|l|}{ Value } & \multirow[t]{2}{*}{ U.M } \\
\hline & & HX1 & HX2 & \\
\hline Minimum section & $S_{\min }=\gamma \cdot S_{1}$ & 1.33 & 1.181 & {$\left[\mathrm{~m}^{2}\right]$} \\
\hline $\begin{array}{l}\text { Maximum velocity } \\
\text { primary agent }\end{array}$ & $w_{\max }=\frac{\dot{V}_{1}}{S_{\min }}$ & 19.78 & 19.78 & {$[\mathrm{~m} / \mathrm{s}]$} \\
\hline $\begin{array}{l}\text { Reynolds number } \\
\text { primary agent }\end{array}$ & $\operatorname{Re}_{1}=\frac{w_{\text {max }} \cdot b}{v_{1}}$ & 9134.7 & 11454.7 & - \\
\hline $\begin{array}{l}\text { Nusselt number } \\
\text { primary agent }\end{array}$ & $N u_{1}$ & 24.7 & 28.6 & - \\
\hline $\begin{array}{l}\text { Heat transfer } \\
\text { coefficient primary } \\
\text { agent }\end{array}$ & $\alpha_{1}=N u_{1} \cdot \frac{\lambda_{1}}{b}$ & 156.8 & 161.5 & {$\left[\mathrm{~W} /\left(\mathrm{m}^{2} \cdot \mathrm{s}\right)\right]$} \\
\hline $\begin{array}{l}\text { Mass flow rate } \\
\text { secondary agent }\end{array}$ & $\dot{m}_{2}=\frac{\dot{Q}}{c_{p 2} \cdot\left(T_{2}^{\prime \prime}-T_{2}^{\prime}\right)}$ & 14.72 & 29.55 & {$[\mathrm{~kg} / \mathrm{s}]$} \\
\hline $\begin{array}{l}\text { Volumetric flow rate } \\
\text { secondary agent }\end{array}$ & $\dot{V}_{2}=\frac{\dot{m}_{2}}{\rho_{2}}$ & 0.015 & 0.03 & {$\left[\mathrm{~m}^{3} / \mathrm{s}\right]$} \\
\hline $\begin{array}{l}\text { Total flow section } \\
\text { secondary agent }\end{array}$ & $S_{2}=\frac{\dot{V}_{2}}{w_{2}}$ & 0.03 & 0.059 & {$\left[\mathrm{~m}^{2}\right]$} \\
\hline Tubes section & $S_{t}=\frac{\pi \cdot d_{e}^{2}}{4}$ & 0.001257 & 0.001257 & {$\left[\mathrm{~m}^{2}\right]$} \\
\hline $\begin{array}{l}\text { Maximum number } \\
\text { calculated of tubes }\end{array}$ & $N_{\text {max.calculat }}=\frac{S_{2}}{S_{t}}$ & 24 & 48 & - \\
\hline Total section tubes & $S_{\text {total }}=N_{\max } \cdot S_{t}$ & 0.03 & 0.06 & {$\left[\mathrm{~m}^{2}\right]$} \\
\hline $\begin{array}{l}\text { Reynolds number } \\
\text { secondary agent }\end{array}$ & $\operatorname{Re}_{2}=\frac{w_{2} \cdot d_{i}}{v_{2}}$ & 20277.5 & 20277.5 & - \\
\hline $\begin{array}{l}\text { Nusselt number } \\
\text { secondary agent }\end{array}$ & $\mathrm{Nu}_{2}$ & 161.4 & 146.2 & - \\
\hline $\begin{array}{l}\text { Heat transfer } \\
\text { coefficient secondary } \\
\text { agent }\end{array}$ & $\alpha_{2}=N u_{2} \cdot \frac{\lambda_{2}}{d_{i}}$ & 2814.8 & 2549.3 & {$\left[\mathrm{~W} /\left(\mathrm{m}^{2} \cdot \mathrm{s}\right)\right]$} \\
\hline $\begin{array}{l}\text { Overall heat transfer } \\
\text { coefficient }\end{array}$ & $k=\frac{1}{\frac{1}{\alpha_{1}}+\frac{\delta}{\lambda_{\text {otel }}}+\frac{1}{\alpha_{2}}}$ & 147.22 & 150.6 & {$\left[\mathrm{~W} /\left(\mathrm{m}^{2} \cdot \mathrm{s}\right)\right]$} \\
\hline Heat exchange area & $S=\frac{\dot{Q}}{k \cdot \Delta T_{m e d}}\left[m^{2}\right]$ & 134.8 & 596.4 & {$\left[\mathrm{~m}^{2}\right]$} \\
\hline $\begin{array}{l}\text { Length tube } \\
\text { (Choose a number of } \\
\text { passes } n_{t r} \text { ) }\end{array}$ & $l=\frac{S}{\pi \cdot d_{e} \cdot N_{\max } \cdot n_{t r}}$ & 7.44 & 16.5 & {$[\mathrm{~m}]$} \\
\hline Number fins & $n_{a}=\frac{l}{b+\delta_{a}}$ & 1354 & 2996 & - \\
\hline
\end{tabular}

PICBE 173

Source: Authors' own research.

\section{Absorption column}

The chemical absorption process requires the existence of two phases: liquid and gas. In this case, the gas phases is represented of the flue gases and the liquid phases of the chemical solvent (Hadri et al., 2017). The chemical solvent is a mixture of 
monoethanolamine (MEA) and water in a different weight ratios (MEA-30\%, $\mathrm{H}_{2} \mathrm{O}-70$ $\%)$.

The equilibrium absorption of carbon dioxide varies according to the height of the absorption column because the kinetics of the chemical reactions between the carbon dioxide and the chemical solvent is a function of temperature, and the temperature profile varies along the absorption column (Pascu et al., 2016). The flue gases velocity through the column is limited by a condition imposed by entrainment gas and liquid phase (Wang et al., 2015). On the other hand, the absorption column is designed for the highest value of the velocity so that the acquisition costs be as low. Considering the large amount of circulated flue gases, the absorption column represents the largest equipment used in the $\mathrm{CO}_{2}$ capture technology. In the column are different packing which are designed to increase the area of the contact between the chemical solvent and the carbon dioxide from flue gases.

The material streams balance in and out of the column is represented by the following equation (Dinca et al., 2015):

$N_{\mathrm{CO}_{2}}=G \cdot\left(Y_{i}-Y_{e}\right)=L \cdot\left(X_{e}-X_{i}\right)\left[k^{2} l_{C_{2}} / h\right]$

where: $\mathrm{N}_{\mathrm{CO}_{2}}$ - is the $\mathrm{CO}_{2}$ flow transferred from the gas phase in the liquid phase, in $\left[\mathrm{kmol}_{\mathrm{CO} 2} / \mathrm{h}\right] ; G$ - is the flow rate of the flue gases, at in/out from the column, in $\left[\mathrm{kmol}_{\mathrm{ga}} / \mathrm{h}\right] ; L$ - is the flow rate of the chemical solvent, at in/out from the column, in $\left[\mathrm{kmol}_{\text {solvent }} / \mathrm{h}\right] ; Y_{i}, Y_{e}$ - is the $\mathrm{CO}_{2}$ concentration in the flue gases, at in/out from the column, in [ $\left.\mathrm{kmol}_{\mathrm{CO} 2} / \mathrm{kmol}_{\mathrm{ga}}\right] ; X_{i}, X_{e}$ - is the $\mathrm{CO}_{2}$ concentration in the chemical solvent, at in/out from the column, in $\left[\mathrm{kmol}_{\mathrm{CO} 2} / \mathrm{kmol}_{\text {solvent }}\right]$.

In order to characterize the chemical absorption process, the $\mathrm{CO}_{2}$ capture efficiency was considered of $90 \%$.

The point of view the thermal condition, the chemical absorption can be performed the isothermal and non-isothermal condition. In the isothermal condition the concentration of the solute in the gas phase is small, and absorption is performed in a high amount of absorbent. In the non-isothermal condition, the concentration of the solute in the gas phase is high, and absorption is performed in a small amount of absorbent. In this case the integral heat of dissolution can increase the liquid phase temperature up to a value at which the desorption process starts. To prevent this situation is realized the cooling of the liquid phase inside or outside column (Wang et al., 2015).

Enthalpy of absorption for MEA at a temperature of $40{ }^{\circ} \mathrm{C}$ is $-50 \mathrm{~kJ}$ for each mole of solvent (Dinca, 2016).

The output optimum temperature of the flue gases and of the chemical solvent is calculated with the following equation (Badea and Dinca, 2012):

$T_{e}=\frac{Q_{g i}+Q_{l i}+Q_{a b}-Q_{p}}{\left(1+\bar{Y}_{e}\right) \cdot G_{m} \cdot c_{p_{g e}}+\left(1+\bar{X}_{e}\right) \cdot L_{m} \cdot c_{p_{l e}}}=56.7\left[{ }^{\circ} \mathrm{C}\right]$

where: $Q_{g i}$ - is the heat of the flue gases the column entry, in [W]; $Q_{l i}$ - is the heat of the chemical solvent the column entry, in [W]; $Q_{a b}$ - is the heat of the absorption, in [W]; $Q_{p}$ are the heat losses; $G_{m}$ - is the mass flow rate flue gases, in $\left[\mathrm{kgga}_{\mathrm{ga}} / \mathrm{s}\right] ; L_{m}$ - is the mass flow rate chemical solvent, in $\left[\mathrm{kg}_{\text {solvent }} / \mathrm{s}\right] ; \bar{Y}_{e}$ - is the $\mathrm{CO}_{2}$ weight concentration in the flue gases at the column exit, in $\left[\mathrm{kg}_{\mathrm{CO} 2} / \mathrm{kgga}\right] ; \bar{X}_{e}$ - is the $\mathrm{CO}_{2}$ weight concentration in the chemical solvent at the column exit, in $\left[\mathrm{kg}_{\mathrm{CO} 2} / \mathrm{kg}_{\text {solvent }}\right] ; c_{p_{g e}}, c_{p_{l e}}$ - are the specific heats at the constant pressure for flue gases/chemical solvent at the column exit, in $[\mathrm{J} /(\mathrm{kg} \cdot \mathrm{K})]$. 
The diameter of the absorption column is a factor that influences the velocity of the phases. The optimal functioning of the column is performed at determinate ratios between the amount the chemical solvent and the velocity (amount) of the gases circulating in countercurrent. To calculating the absorption column diameter with packing is applied Kafarov equation (Kim and Lee, 2017):

$\lg \left(\frac{w_{\hat{\imath}}{ }^{2} \cdot \sigma \cdot \rho_{g} \cdot \eta_{l}{ }^{0.16}}{g \cdot V_{l}^{3} \cdot \rho_{l}}\right)=A-1.75 \cdot\left(\frac{L}{G}\right)^{0.25} \cdot\left(\frac{\rho_{g}}{\rho_{l}}\right)^{0.125}$

where: $w_{\hat{i n}}$ - is the flooding vapor velocity, in $[\mathrm{m} / \mathrm{s}] ; \quad \sigma$ - is the surface area of the packing, in $\left[\mathrm{m}^{2} / \mathrm{m}^{3}\right] ; g$ is the gravitational acceleration, in $\left[\mathrm{m} / \mathrm{s}^{2}\right] ; V_{l}$ - is free volume of the packing, in $\left[\mathrm{m}^{3} / \mathrm{m}^{3}\right] ; \rho_{g}$ and $\rho_{l}$ - are the densities of the flue gases and the chemical solvent, in $\left[\mathrm{kg} / \mathrm{m}^{3}\right] ; \eta_{l}$ - is the dynamic viscosity of the chemical solvent, in [Pa's]; $L$ and $G$ - are the mass flow rate of the flue gases and chemical, in $[\mathrm{kg} / \mathrm{s}] ; A=0.022$, for packing rings and spirals.

The type of the packing influences the absorber column size and implicitly the acquisition costs. In the table below are presented the characteristics of different types of packing studied in this article.

Table 5. Operational data PALL-Rings

\begin{tabular}{|c|c|c|c|c|c|}
\hline \multirow[t]{2}{*}{$\begin{array}{l}\text { Type } \\
\text { PALL-Rings }\end{array}$} & Size & Weight & Number & $\begin{array}{l}\text { Specific } \\
\text { Surface }\end{array}$ & Free volume \\
\hline & {$[\mathrm{mm}]$} & {$\left[\mathrm{kg} / \mathrm{m}^{3}\right]$} & [per m³] & {$\left[\mathrm{m}^{2} / \mathrm{m}^{3}\right]$} & {$[\%]$} \\
\hline Metal & $25 \times 25 \times 0.6$ & 460 & 51000 & 215 & 95 \\
\hline Stoneware/porcelain & $25 \times 25 \times 3$ & 620 & 39900 & 220 & 75 \\
\hline Plastics & $25 \times 25$ & 75 & 54600 & 220 & 91 \\
\hline
\end{tabular}

Source: Pascu et al., 2016.

The height of the absorption column with packing is determined by the height of the layer packing. The height of the layer packing resulted from the equation of the effective mass transfer area (Liang et al., 2016).

The effective height of the absorption column is calculated by the equation [13]:

$H_{\text {col.abs }}=n_{\text {str }} \cdot h_{u}+\left(n_{\text {str }}-1\right) \cdot h_{1}+h_{2}+h_{3}=38.4 \mathrm{~m}$

where: $h_{1}$ - is the distance between two layers of packing $(0.5 \div 1 \mathrm{~m}) ; h_{1}=0.5 \mathrm{~m} ; h_{2}$ - is the distance from the top of the first layer of packing to the top of the column $(1 \div 1.5$ $\mathrm{m}) ; h_{2}=1 \mathrm{~m} ; h_{3}$ - is the distance from the bottom of the last layer of packing up the bottom of the column $(1 \div 2 \mathrm{~m}) ; h_{3}=1 \mathrm{~m}$.

In the Table 6 are presented results obtained for the size of the absorption column according to the type of the packing used.

Table 6. Sizes absorption column

\begin{tabular}{|l|l|l|l|l|l|}
\hline \multirow{2}{*}{$\begin{array}{l}\text { Type } \\
\text { PALL-Rings }\end{array}$} & $\begin{array}{l}\text { Flooding } \\
\text { velocity }\end{array}$ & $\begin{array}{l}\text { Diameter } \\
\text { column }\end{array}$ & $\begin{array}{l}\text { Packing } \\
\text { height }\end{array}$ & $\begin{array}{l}\text { Column } \\
\text { height }\end{array}$ & $\begin{array}{l}\text { Mass } \\
\text { column }\end{array}$ \\
\cline { 2 - 5 } & {$[\mathrm{m} / \mathrm{s}]$} & {$[\mathrm{m}]$} & {$[\mathrm{m}]$} & {$[\mathrm{m}]$} & {$[\mathrm{t}]$} \\
\hline Metal & 2.728 & 10.3 & 35.9 & 40.4 & 1462.7 \\
\hline Stoneware/porcelain & 1.892 & 12.4 & 25.1 & 29.5 & 1948.3 \\
\hline Plastics & 2.529 & 10.7 & 33.4 & 37.9 & 296.6 \\
\hline
\end{tabular}

Source: Authors' own research.

\section{Desorption column}

Order to the desorption process using a column to which sizing is performed the same as that of the absorption column. Thus, for desorption column (Figure 4), we only calculated the necessary stripping steam. 


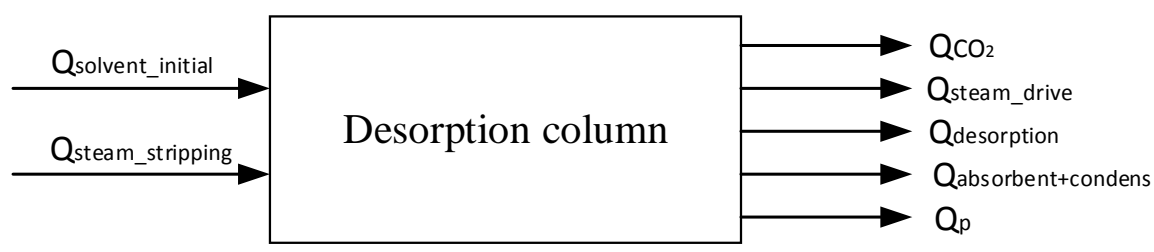

Figure 4. Heat balance of desorption column

Source: Hadri et al., 2017.

The general equation of the heat flow balance to the desorption column is:

$Q_{\text {initial_solvent }}+Q_{\text {steam_stripping }}=Q_{\mathrm{CO}_{2}}+Q_{\text {steam_drive }}+Q_{\text {desorption }}+Q_{\text {absorbentcondens }}+Q_{p}$

Table 7. Equations to calculate the steam ratio for solvent regeneration

\begin{tabular}{|c|c|c|}
\hline Parameter & Notation & U.M \\
\hline Mass flow rate $\mathrm{CO}_{2}$ rich solvent & $L$ & {$[\mathrm{~kg} / \mathrm{s}]$} \\
\hline Maximum flow rate steam & $\dot{m}_{\text {steam }}$ & {$[\mathrm{kg} / \mathrm{s}]$} \\
\hline Mass flow rate $\mathrm{CO}_{2}$ & $\dot{m}_{\mathrm{CO}_{2}}$ & {$[\mathrm{~kg} / \mathrm{s}]$} \\
\hline Mass flow rate steam drive & $\dot{m}_{\text {steam_drive }}$ & {$[\mathrm{kg} / \mathrm{s}]$} \\
\hline Inlet temperature $\mathrm{CO}_{2}$ rich solvent & $T_{i, \text { solvent }}$ & {$[\mathrm{K}]$} \\
\hline Outlet temperature $\mathrm{CO}_{2}$ rich solvent & $T_{e, \mathrm{CO}_{2}}$ & {$[\mathrm{~K}]$} \\
\hline $\begin{array}{l}\text { Outlet temperature absorbent and } \\
\text { condense }\end{array}$ & $T_{e}$ & {$[\mathrm{~K}]$} \\
\hline Specific heat $\mathrm{CO}_{2}$ rich solvent & $c_{p, \text { solvent }}$ & {$[\mathrm{J} /(\mathrm{kg} \cdot \mathrm{K})]$} \\
\hline $\begin{array}{l}\text { Specific heat } \mathrm{CO}_{2} \text { at outlet } \\
\text { temperature }\end{array}$ & $c_{p, \mathrm{CO}_{2}}$ & {$[\mathrm{~J} /(\mathrm{kg} \cdot \mathrm{K})]$} \\
\hline Specific heat $\mathrm{H}_{2} \mathrm{O}$ & $c_{p, \mathrm{H}_{2} \mathrm{O}}$ & {$[\mathrm{J} /(\mathrm{kg} \cdot \mathrm{K})]$} \\
\hline $\begin{array}{l}\text { Enthalpy steam at temperature in } \\
\text { column }\end{array}$ & $i_{\text {steam }}$ & {$[\mathrm{J} / \mathrm{kg}]$} \\
\hline Heat dissolution $\mathrm{CO}_{2}$ & $-\Delta H_{a b}$ & {$[\mathrm{~J} / \mathrm{kg}]$} \\
\hline Overall heat transfer coefficient & $k$ & {$\left[\mathrm{~W} /\left(\mathrm{m}^{2} \cdot \mathrm{K}\right)\right]$} \\
\hline Heat exchange area insulation & $S_{i z}$ & {$\left[\mathrm{~m}^{2}\right]$} \\
\hline Mean temperature difference & $\Delta T_{m}$ & {$[\mathrm{~K}]$} \\
\hline Parameter & Equation & U.M \\
\hline $\begin{array}{l}\text { Heat flow introduced to chemical } \\
\text { solvent }\end{array}$ & $Q_{\text {initialt_slvent }}=L \cdot c_{p, \text { solvent }} \cdot T_{i, \text { solvent }}$ & {$[\mathrm{J} / \mathrm{s}]$} \\
\hline $\begin{array}{l}\text { Heat flow introduced to steam } \\
\text { stripping }\end{array}$ & $Q_{\text {steam_stripping }}=\dot{m}_{\text {steam }} \cdot i_{\text {steam }}$ & {$[\mathrm{J} / \mathrm{s}]$} \\
\hline Heat flow of $\mathrm{CO}_{2}$ output & $Q_{\mathrm{CO}_{2}}=\dot{m}_{\mathrm{CO}_{2}} \cdot c_{p, \mathrm{CO}_{2}} \cdot T_{e, \mathrm{CO}_{2}}$ & {$[\mathrm{~J} / \mathrm{s}]$} \\
\hline Heat flow steam drive & $Q_{\text {steam_drive }}=\dot{m}_{\text {steam_drive }} \cdot i_{\text {steam }}$ & {$[\mathrm{J} / \mathrm{s}]$} \\
\hline Heat flow desorption & $Q_{\text {desorption }}=-\Delta H_{a b} \cdot \dot{m}_{\mathrm{CO}_{2}}[\mathrm{~W}]$ & {$[\mathrm{J} / \mathrm{s}]$} \\
\hline Heat flow absorbent and condense & $\begin{array}{l}Q_{\text {absorbent+condens }}=\left(L+\dot{m}_{\text {steam }}-\dot{m}_{\text {steam_drive }}\right) \\
\cdot c_{p, \mathrm{H}_{2} \mathrm{O}} \cdot T_{e}\end{array}$ & {$[\mathrm{~J} / \mathrm{s}]$} \\
\hline Losses heat flow insulation layer & $Q_{p}=k \cdot S_{i z} \cdot \Delta T_{m e d}$ & {$[\mathrm{~J} / \mathrm{s}]$} \\
\hline
\end{tabular}

Source: Kim and Lee, 2017.

The steam ratio for solvent regeneration $\left(\dot{m}_{\text {steam }}[\mathrm{kg} / \mathrm{s}]\right)$ resulted of the equation of the heat balance (Table 7) for which the steam index is of $0.775 t_{\text {steam }} / t_{\text {co2 }}$. Also, it was 
calculated the consumption index to capture a ton of $\mathrm{CO}_{2}$, it is of $2.95 \mathrm{GJ} / \mathrm{t}_{\mathrm{CO} 2}$. The result obtained is validated by the results of the scientific literature.

\section{Results}

The type of the packing influences the size of the absorption column and implicitly the cost of investment. We analyzed different type packing PALL-Rings: metal, stoneware/porcelain and plastics. In the case we used the PALL-Rings of metal the diameter of the absorption column (Figure 5) obtained was of $10.3 \mathrm{~m}$, the higher value for diameter is in the case we used the PALL-Rings of stoneware/porcelain $(12.4 \mathrm{~m})$. The diameter of the column varies with the flooding vapor velocity, in the Figure 6 it is observed that with increasing the flooding velocity the diameter is smaller.

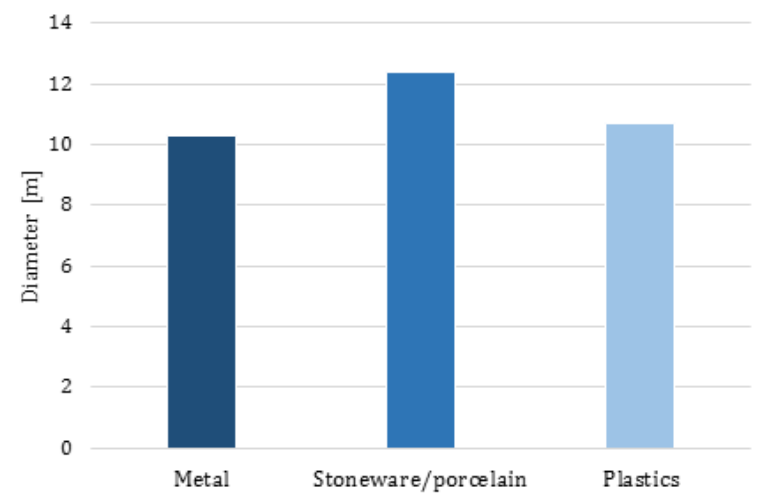

Figure 5. Diameter column absorption according to type packing

Source: Authors' own research.

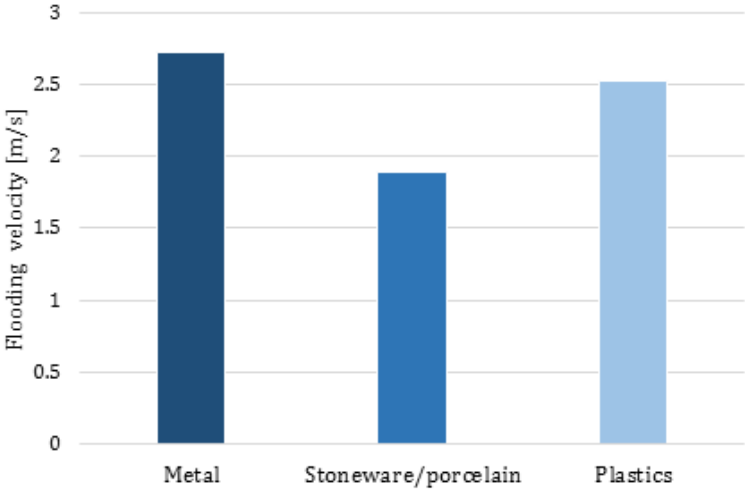

Figure 6. Flooding vapor velocity according to type packing

Source: Authors' own research.

The packing and the effective column height (Figure 7) varies according to the characteristics of the type packing used. The packing height for the stoneware/porcelain is of $25.1 \mathrm{~m}$, for the plastics is of $33.4 \mathrm{~m}$ and for the metal is of 35.9 . The characteristic which influences this values is the free volume for all of them. In the Figure 8 is represented the packing height according to the free volume. It is observed that in the case of the packing stoneware/porcelain the free volume is of $75 \%$, for the plastics is of $91 \%$ and for the metal is of $95 \%$.

In the Figure 9 are shown the mass absorption column for the packings studied in this study. The weight is small for the plastics and bigger for the stoneware/porcelain. The cost of the absorption column varies (Figure 10) according to the mass of the absorption column. The least cost investment is for an absorption column with packing of plastics. 


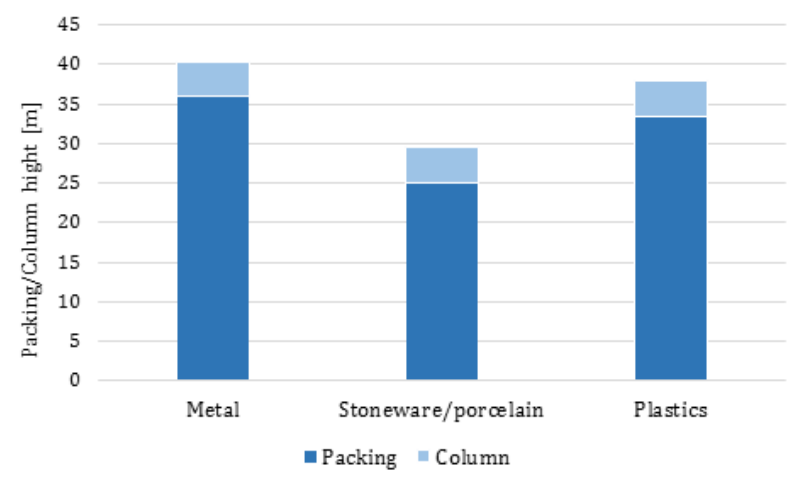

PICBE 178

Figure 7. Packing and effective column absorption height according to type packing Source: Authors' own research.

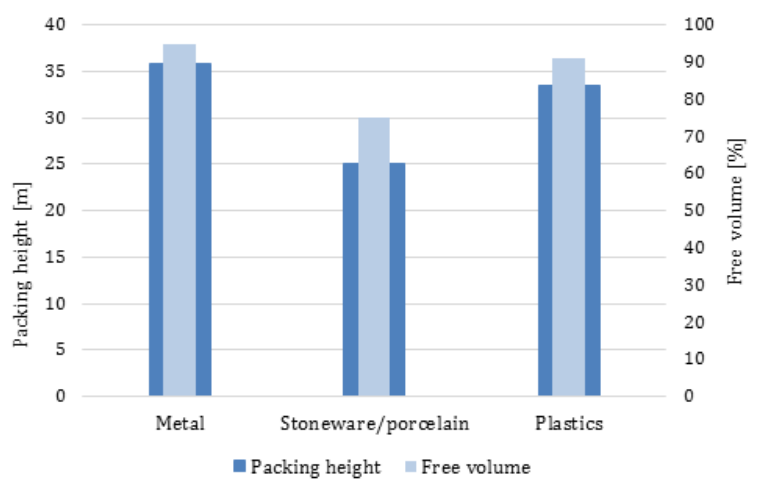

Figure 8. Packing column height according to free volume of type packing

Source: Authors' own research.

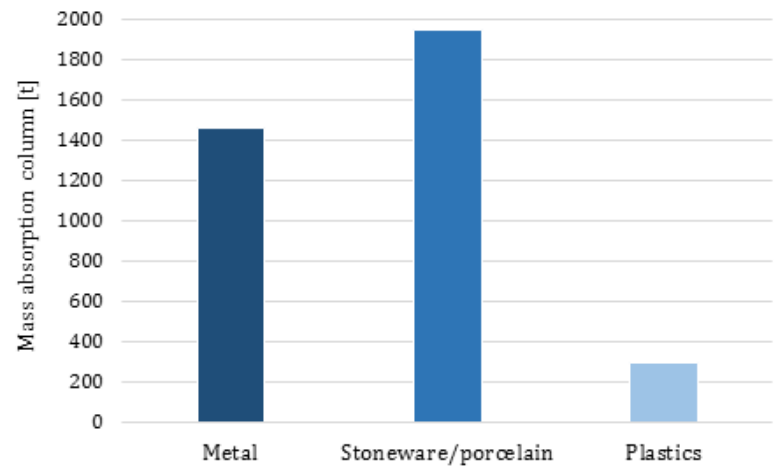

Figure 9. Mass absorption column according to type packing

Source: Authors' own research.

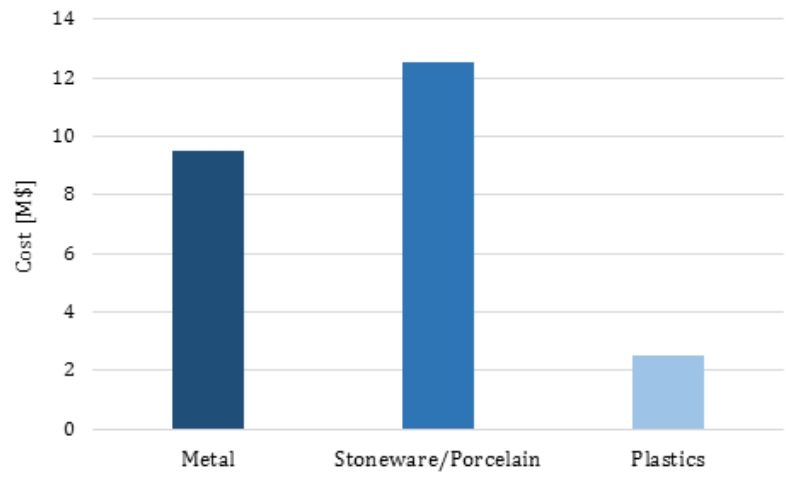

Figure 10. Cost absorption column according to type packing

Source: Authors' own research. 


\section{Conclusions}

In this study we analyzed the $\mathrm{CO}_{2}$ capture technology by chemical absorption, it was integrated in a power plant with power installed of $100 \mathrm{MW}$. The amine used was monoethanolamine in weight $30 \%$. The efficiency of $\mathrm{CO}_{2}$ capture was considered of 90 $\%$. The capturing a ton of $\mathrm{CO}_{2}$ requires $2.95 \mathrm{GJ}$, this amount of thermal energy for the solvent regeneration is obtained by using a steam ratio from the low pressure steam turbine. The size of the equipments depends the flow rate of the flue gases, the $\mathrm{CO}_{2}$ concentration in the flue gases, the $\mathrm{CO}_{2}$ capture efficiency and the type amine used.

The size of the absorption column varies according to the characteristics of the type packing used. We analyzed different packings, respectively PALL-Rings made of metal, stoneware/porcelain and plastics. After the economical evaluation, the best option for the type of the packing resulted PALL-Rings of plastics.

\section{Acknowledgements}

The study has been funded by the UEFISCDI within the National Project number 51/2017 with the title: „Optimization and validation of the $\mathrm{CO}_{2}$ capture demonstrative pilot installation by chemical absorption technology" - CHEMCAP.

\section{References}

Badea, A.A., Dinca, C.F. (2012). $\mathrm{CO}_{2}$ capture from post-combustion gas by employing MEA absorption process-experimental investigations for pilot studies. University" Politehnica" of Bucharest Scientific Bulletin, Series D: Mechanical Engineering, 74(1), 21-32.

Badea, A.A., Voda, I., Dinca, C.F., (2010). Comparative analysis of coal, natural gas and nuclear fuel life cycles by chains of electrical energy production. University" Politehnica" of Bucharest Scientific Bulletin, Series C-Electrical Engineering and Computer Science Volume, 72, 221-238.

Dinca, C. (2013). Technical, environmental and economic assessment of $\mathrm{CO}_{2}$ absorption chemical process integration in the power plant technologies. Book: Materials and processes for energy: communicating current research and technological developments. Editor: A. Méndez-Vilas, Formatex Research Center, Spain, 935-945.

Dinca, C., Badea, A. (2013). The parameters optimization for a CFBC pilot plant experimental study of post-combustion $\mathrm{CO}_{2}$ capture by reactive absorption with MEA. International Journal of Greenhouse Gas Control, 12, 269-279.

Dinca, C., Badea, A., Stoica, L., Pascu, A. (2015). Absorber design for the improvement of the efficiency of post-combustion $\mathrm{CO}_{2}$ capture.Journal of the Energy Institute, 88(3), 304-313.

Dinca, C. (2016). Critical parametric study of circulating fluidized bed combustion with $\mathrm{CO}_{2}$ chemical absorption process using different aqueous alkanolamines. Journal of Cleaner Production, 112, 1136-1149.

Hadri, E.N., Quang, D.V., Goetheer, E.L., Abu-Zahra, M.R. (2017). Aqueous amine solution characterization for post-combustion $\mathrm{CO}_{2}$ capture process. Applied Energy, 185, 1433-1449.

Kim, H., Lee, K.S. (2017). Energy analysis of an absorption-based $\mathrm{CO}_{2}$ capture process. International Journal of Greenhouse Gas Control, 56, 250-260.

Liang, Z., Fu, K., Idem, R., Tontiwachwuthikul, P. (2016). Review on current advances, future challenges and consideration issues for post-combustion $\mathrm{CO}_{2}$ capture using amine-based absorbents. Chinese Journal of Chemical Engineering, 24(2), 278-288. 
Norișor, M., Badea, A., Dinca, C., (2012). Economical and technical analysis of $\mathrm{CO}_{2}$ transport ways. University Politehnica of Bucharest Scientific Bulletin Series CElectrical Engineering and Computer Science Volume, 74, 127-138.

Pascu, A., Stoica, L., Dinca, C., Badea, A. (2016). The package type influence on the performance of the $\mathrm{CO}_{2}$ capture process by chemical absorption. University Politehnica of Bucharest scientific bulletin series c-electrical engineering and computer science, 78(1), 259-270.

Porter, R.T., Fairweather, M., Kolster, C., Mac Dowell, N., Shah, N., Woolley, R.M. (2016). Cost and performance of some carbon capture technology options for producing different quality $\mathrm{CO}_{2}$ product streams. International Journal of Greenhouse Gas Control.

Rahman, F.A., Aziz, M.M.A., Saidur, R., Bakar, W.A.W.A., Hainin, M.R., Putrajaya, R., Hassan, N.A. (2017). Pollution to solution: Capture and sequestration of carbon dioxide $\left(\mathrm{CO}_{2}\right)$ and its utilization as a renewable energy source for a sustainable future. Renewable and Sustainable Energy Reviews, 71, 112-126.

Singh, S., Sørensen, K., Simonsen, A.S., Condra, T.J. (2017). Implications of fin profiles on overall performance and weight reduction of a fin and tube heat exchanger. Applied Thermal Engineering, 115, 962-976.

Wang, M., Joel, A. S., Ramshaw, C., Eimer, D., Musa, N.M. (2015). Process intensification for post-combustion $\mathrm{CO}_{2}$ capture with chemical absorption: a critical review. Applied Energy, 158, 275-291. 